\title{
A SELECTIVE METHOD FOR THE DEMONSTRATION OF BIFID BACTERIA (LACTOBACILLUS BIFIDUS) IN MATERIALS TESTED FOR FAECAL CONTAMINATION
}

\author{
Helge Gyllenberg and Seppo Niemelä
}

Department of Microbiology, University of Helsinki

Received November 29, 1958

In the search for new and, if possible, more specific bacterial indicators of faecal contamination in foods and water, attention has recently been paid also to the Gram positive, anaerobic intestinal bacteria which mostly are referred to as Lactobacillus bifidus in the literature (5). Organisms of this type consitute the major part of the intestinal vegetation of milk-fed infants, but they are regularly encountered in high numbers also in the faeces of adults (e.g. ref. 4). Dehnert (1) has described 4 different subtypes in this group. These subtypes can be distinguished on the basis of fermentation reactions and basic nutritional demands (1, 3; cf. Tables 1 and 2), and it seems that some of them are specific for certain habitats $(2,3,7)$. The subtype occurring regularly in the faeces of human adults is referred to as type $B_{1}$ in tables 1 and 2 , and it seems most convenient, therefore, to select this subtype as an indicator in the demonstration of faecal contamination in foods and/or water samples on the basis of the occurrence of bifid bacteria. A selective method for the enumeration of type $\mathrm{B}_{1}$, including the use of a simple synthetic medium, would therefore be very useful in investigations of this kind.

Table 1. Characteristic fermentation reactions of the different ubtypes of bifid bacteria $(+$ indicates fermentation, 0 no fermentation).

\begin{tabular}{lcccccc} 
Subtypes & \multicolumn{7}{c}{ Fermentation of } \\
& Glucose & Lactose & Xylose & Arabinose & Melezitose & Sorbitol \\
$\mathrm{A}$ & + & + & + & 0 & 0 & 0 \\
$\mathrm{~B}_{1}$ & + & + & + & + & + & 0 \\
$\mathrm{~B}_{2}$ & + & + & 0 & 0 & + & + \\
$\mathrm{C}$ & + & + & 0 & 0 & 0 & 0
\end{tabular}


Table 2. Basic nutritional demands of the different subtypes of bifid bacteria $(+$ indicates essential nature of the given substance, $s$ stimulatory effect, and 0 no dependence). The following abreviations are employed: $\mathrm{B}=$ biotine, $\mathrm{Pa}=$ pantothenic acid, $\mathrm{P}=$ pantethine, $\mathrm{R}=$ riboflavine, $\mathrm{Pep}=$ peptide factor, $\mathrm{As}=$ amino sugar factor, $\mathrm{PPB}=$ Mixture of purine and pyrimidine bases, Oa $=$ oleic acid, $\mathrm{C}=$ cystine.

$\begin{array}{cccccccccc}\text { Subtypes } & \mathrm{B} & \mathrm{Pa} & \mathrm{P} & \mathrm{R} & \mathrm{Pep} & \mathrm{As} & \mathrm{PPB} & \mathrm{Oa} & \mathrm{C} \\ \mathrm{A} & + & + & 0 & 0 & 0 & 0 & 0 & \mathrm{~s} & + \\ \mathrm{B}_{1} & \mathrm{~s} & & + & + & \mathrm{s} & 0 & 0 & \mathrm{~s} & + \\ \mathrm{B}_{2} & \mathrm{~s} & & + & + & \mathrm{s} & 0 & 0 & \mathrm{~s} & + \\ \mathrm{C} & \mathrm{s} & & + & + & +/ \mathrm{s} & + & + & \mathrm{s} & +\end{array}$

\section{Description of the method}

A simple medium for the enumeration of type A which predominates in breastfed infants has been developed by Petuely $(6,8)$. As shown in Table 2 the nutritional demands of type $\mathrm{B}_{1}$ are somewhat more complex than those of type $\mathrm{A}$. The difference is that type $B_{1}$ requires riboflavine, and most strains also preformed pantethine. The medium of PETUely must thus be modified so as to contain also riboflavine and pantethine in order to satisfy the requirements of type $B_{1}$. Since type $A$, on the other hand, fails to utilize arabinose, the medium becomes selective for type $B_{1}$ if arabinose replaces lactose as the source of energy. The medium for a selective enumeration of has the following composition.

$\begin{array}{lcllcc}\mathrm{L}(+) \text {-arabinose } & 1 & \mathrm{~g} & \mathrm{FeSO}_{4} 7 \mathrm{H}_{2} \mathrm{O} & 1 & \mathrm{mg} \\ \text { Cysteine-HCl } & 0.04 \mathrm{~g} & \mathrm{MnSO}_{4} \cdot 4 \mathrm{H}_{2} \mathrm{O} & 0.7 & \mathrm{mg} \\ \mathrm{K}_{2} \mathrm{HPO}_{4} & 0.5 & \mathrm{~g} & \mathrm{NaCl} & 1 & \mathrm{mg} \\ \left(\mathrm{NH}_{4}\right)_{2} \mathrm{SO}_{4} & 0.4 & \mathrm{~g} & \text { Sodium ascorbinate (in terms of } & & \\ \text { Tween } 80 & 0.1 & \mathrm{~g} & \text { ascorbic acid) } & 1 & \mathrm{~g} \\ \text { Pantethine } & 50 & \mu \mathrm{g} & \text { Washed agar } & 2 & \mathrm{~g} \\ \text { Riboflavine } & 25 & \mu \mathrm{g} & \text { Distilled water } & 100 & \mathrm{ml} \\ \text { Biotine } & 0.5 & \mu \mathrm{g} & \text { pH is adjusted to } 6.8-7.0 & & \\ \text { MgSO }_{4} \cdot 7 \mathrm{H}_{2} \mathrm{O} & 20 & \mathrm{mg} & & \end{array}$

This medium is prepared in two lots, one of which contains all the components except arabinose and ascorbic acid at double strength. This lot can be sterilized by ordinary autoclaving. The other lot is prepared by dissolving $1 \mathrm{~g}$ ascorbic acid in distilled water; $1-\mathrm{N} \mathrm{NaOH}$ is added to bring the $\mathrm{pH}$ into the range of $6.8-7.0$. $1 \mathrm{~g}$ arabinose is then dissolved in this Na-ascorbinate solution, and distilled water is added to bring the volume to $50 \mathrm{ml}$. This solution is sterilized by filtration. Equal volumes of the ascorbinate-arabinose solution (heated to $55-60^{\circ}$ ) and the melted agar lot (cooled to $55-60^{\circ}$ ) are then mixed, the mixture is poured on plates and allowed to solidify. Overheating of the ascorbinate-arabinose solution must be avoided since it gives rise to oxidation of the ascorbic acid.

The plates of the final medium are inoculated for the enumeration of type $B_{1}$ with suitable dilutions of the material to be tested by means of the "surface drop" 
method. The testing of the water samples can be performed with the membrane filter method. In order to facilitate the counting of the colonies from the membranes we have used an 0.01 per cent concentration of 2,3,5-triphenyltetrazolum chloride (referred to below as TTC) in the medium. TTC was added to the ascorbinate-arabinose solution immediately before filtration. In the presence of TTC, overheating of the solution results in the spontaneous precipitation of TTC as formazan, the critical point seems to be as low as about $40^{\circ} \mathrm{C}$.

Incubation is performed at $37^{\circ} \mathrm{C}$ in carbon dioxide for 48 hours. For this purpose ordinary laboratory desiccators can be employed. They are emptied to about $10-15 \mathrm{~mm} \mathrm{Hg}$ with a water pump, and are then filled with commercial $\mathrm{CO}_{2}$. Under these conditions type $\mathrm{B}_{1}$ grows on the synthetic agar in the form of smooth, circular and convex colonies. They are almost colorless, have entire margins, and are $0.2-2 \mathrm{~mm}$ in diameter. In the presence of TTC flakes of red precipitate appear in the colonies, which are thus easily distinguished from the background (Figure 1).

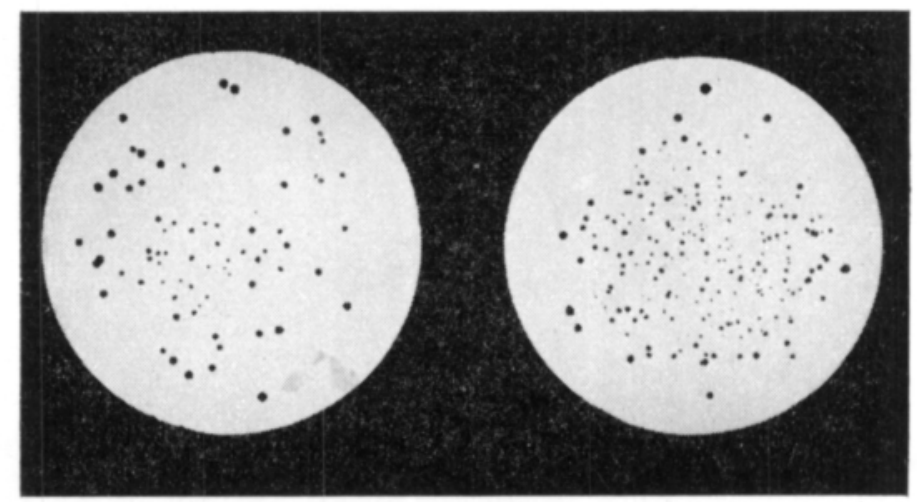

Figure 1. Colonies of type $B_{1}$ on membranes incubated on selective synthetic agar containing TTC.

\section{Experiences gained from of the method in use.}

We have employed the method described above for testing faecal samples of human (adult) origin, samples of water artificially polluted with faeces, and ordinary water samples. A considerable number of the colonies which grew on the synthetic medium in the experiments were examined microscopically, and it was found that only less than 1 per cent of the colonies were representative of organisms other than bifid bacteria. In the concentration of TTC employed by us a slight reduction (15-40 per cent) in the numbers of type $B_{1}$ colonies was observed. Since the type $B_{1}$ figures nevertheless remained 10-100 times higher than those of coliform organisms (Congo agar) or enterococci (M Enterococcus agar; 9) determined from the same samples, it appears that the addition of TTC does not effect a considerable loss in the relative sensitivity of the method. The significance of type $B_{1}$ in foods and water is still to be assessed accurately, but for the present it can be concluded that the method described here is highly selective for type $B_{1}$ which is a typical intestinal organism, though hitherto not proved as occurring regularly in other environments. 


\title{
$S u m m a r y$
}

A method which permits a selective enumeration of a subtype of the organisms hitherto referred to as Lactobacillus bifidus, known as an ordinary inhabitant of the intestines of human adults, is described. It is suggested that this method may be useful for the demonstration of organisms of this kind in foods and water as indicators of faecal pollution.

\section{REFERENCES.}

(1) Dehnert, J. 1957. Untersuchung über die gram-positive Stuhlflora des Brustmilchkindes. Zbl. Bakt., I Orig. 169: 66-79.

(2) Gyllenberg, H. \& Carlberg, G. 1958. The dominance of a specific nutritional type of Lactobacillus bifidus in breast-fed infants. Acta Path. et Microbiol. Scand. 42: 380 - 384.

(3) - - \& - 1958. The nutritional characteristics of the bifid bacteria (Lactobacillus bifidus) of infants. Ibid. 44: 287-292.

(4) Haenel, H. \& Müller-Beuthow, W. 1956. Vergleichende quantitative Untersuchungen über Keimzahlen in den Faeces des Menschen und einiger Wirbeltiere. Zbl. Bakt. I Orig. 167: $123-133$.

(5) Mossel, D. A. A. 1958. The suitability of bifidibacteria as part of a more extended bacterial association, indicating faecal contamination of foods. VIIth Intern. Congr. Microbiol. Abstr. of Papers p. 440.

(6) Petuely, F. 1956. Ein einfacher vollsynthetischer Selektivnährboden für den Lactobacillus bifidus. Zbl. Bakt. I Orig. 166: 95-99.

(7) - - 1957. Biochemische Untersuchungen zur Regulation der Dickdarmflora des Däuglings (Über den Bifidusfaktor). 96 p. Graz.

(8) - - \& LyNAU, V. 1954. Ein einfacher vollsynthetischer Optimalnährboden für den Lactobacillus bifidus. (Ứber die Bedeutung der Ascorbinsäure für das Wachstum des Lactobacillus bifidus). Biochem, Z. 326: 62-78.

(9) Slanetz, L. W. \& Bartley, C. H. 1957. Numbers of enterococci in water, sewage, and feces determined by the membrane filter technique with an improved medium. J. Bact. 74: $591-595$.

\section{SELOSTUS:}

\section{VALIKOIVA MENETELMÄ "BIFIDIBAKTEERIEN" (LACTOBACILLUS BIFIDUS) OSOITTAMISEKSI FEKAALISEN SAASTUMISEN SUHTEEN TUTKITUISTA NÄYTTEISTÄ}

\author{
Helge Gyllenberg ja Seppo Niemelä \\ Mikrobiologian laitos, Helsingin yliopisto
}

Esitetään menetelmä, jonka avulla erään Lactobacillus bifiduksen alatyypin valikoiva viljeleminen on mahdollista. Koska ko. bakteeria aina tavataan varsin runsaasti aikuisten ulosteissa on todennäköistä, että sen esiintyminen esimerkiksi vesi- ja elintarvikenäytteissä on fekaalisen kontaminaation herkkä indikaattori. Nyt kuvattu menetelmä näyttäisi siten soveltuvan tällaisen kontaminaation osoittamiseen. 